\title{
A Study on the Morphometric Variation in Selected Ichthyofauna under Genus Puntius Hamilton-Buchanan (Teleostei: Cyprinidae)
}

\author{
${ }^{1}$ S. Choudhury, ${ }^{2}$ Dr. K. Dutta \\ ${ }^{1,2}$ Department of Zoology, Gauhati University, Guwahati-14, Assam, India.
}

\begin{abstract}
Morphometric studies were conducted using eleven quantitative body parameters of six species of Puntius genus - Puntius chola, P. gelius, P. conchonius, P. sophore, P. sarana sarana and P. ticto ticto occurring from Assam, India, in order to study the morphometric variation and interrelationship among these species. All measurements were taken on a continuous scale using digital vernier caliper parallel to the anterior-posterior body axis except for the body depth that was taken perpendicular to the body axis between dorsal and ventral margins. The means of all measurements were standardized. A correlation study between total length vs. other morphometric parameters and a multivariate principal component analysis were conducted using MS Excel and bdpro32 software. The results obtained showed a significant correlation between total length and other morphometric parameters $(p<0.05)$ except for total length and pre-orbital length. The scores of PC1, PC2 and PC3 were found to be most similar for P. sarana sarana and P. gelius indicating these two species to be most closely related followed by P.ticto ticto , P. chola and P. conchonius, while the PC scores of $P$. sophore were the most dissimilar. The findings of this study will help in developing new strategies for conservation and breeding programmes of these species.
\end{abstract}

Keywords: Morphometric studies, Puntius genus, morphometric variation, interrelationship, principal component analysis.

\section{Introduction:}

Body shape is a difficult but important trait to quantify. The word morphometrics is derived from two Greek words: "morph", meaning shape or form and "metron", meaning measurement. Complex variation associated with body form is one of the most difficult types of variation to quantify and the methods used to access it are collectively referred to as morphometrics [1]. These methods are concerned with quantifying shape variation within and among samples usually to address developmental and evolutionary questions relating to shape change during growth. Morphometrics is a field concerned with studying variation and change in the form (size and shape) of organisms or objects [2]. There are several methods for extracting data from shapes, each with their own benefits and weaknesses. These include measurement of lengths and angles, landmark analysis and outline analysis. Morphometrics adds a quantitative element to descriptions, allowing more rigorous comparisons. It enables one to describe complex shapes in a rigorous fashion and permits numerical comparison between different forms [3] and when combined with multivariate statistical methods (e.g. Principal Component Analysis, Cluster Analysis etc) they offer powerful tool for testing and displaying differences in shape [4] [5]. All landmark based morphometric methods face the fundamental challenge of removing variation in size from variation in shape. Traditional morphometrics uses one of three general approaches to try to isolate shape from size variation: ratios, regression and multivariate factor or component analysis [6] [7].

The state of Assam, India, which lies in two biodiversity hotspot regions of the world (The Himalayas and the Indo-Burma), harbours a large variety of threatened and endemic flora and fauna including a large variety of fishes. Since fishes are the most ancient group of the vertebrates, their diversity and taxonomic studies is very essential. Cyprinids are the major component of Indian freshwater fish fauna with respect to the number both of individuals and of species. The role of this family within freshwater ecosystem is therefore central. Fishes of the genus Puntius under Cyprinidae family are prolific and are known to occupy all niches [8]. The genus Puntius is of much importance as many species under this genus are ornamental species, some food species, some are used for extracting oil and some are considered to be of medicinal value etc. Morphometric characters have been commonly used in fisheries biology as powerful tools for measuring discreteness and relationships among various taxonomic categories [9].

Application of morphometrics in Puntius genus for study of taxonomic relationship is limited and is still an open issue in this region. Thus, the present study had been undertaken with the main objective to analyze possible morphometric variation and interrelationship among the selected species.

\section{Materials \& Methods:}

A total of sixty specimens; ten for each of the six species of fish of Puntius genus under Cyprinidae family - Puntius chola, P.gelius, P. conchonius, P. sophore, P. sarana sarana and P. ticto ticto were collected 
from the water bodies of Assam by random sampling. The species were identified by the characters described by [10] [11]. No significant sexual dimorphisin with respect to the selected morphometrics was observed; therefore the data analyses were performed without taking the sex of the individual into consideration.

Eleven measurements (Fig: 1) were taken from the lateral side of the fish on a continuous scale using digital vernier caliper. All lengths were taken parallel to the anterior-posterior body axis except for the body depth that was taken perpendicular to the body axis between dorsal and ventral margins [12]. The mean of the data for each species were calculated and also the standard deviation. The mean values have been used for the analyses (Table 1). Besides effects from the environment and evolutionary history, morphometric characters may contain growth and/or allometric trends. To correct for (relative) differences in size all measurements have been standardized (expressed as proportions of total length Vs other measurements, Table 2). Moreover, selecting specimens from a specific size range may also contribute in the elimination of growth trends. A correlation study between Total length and other morphometric parameters and a principal component analysis were conducted using the standardized morphometric data with the help of MS Excel and bdpro32 software [13].

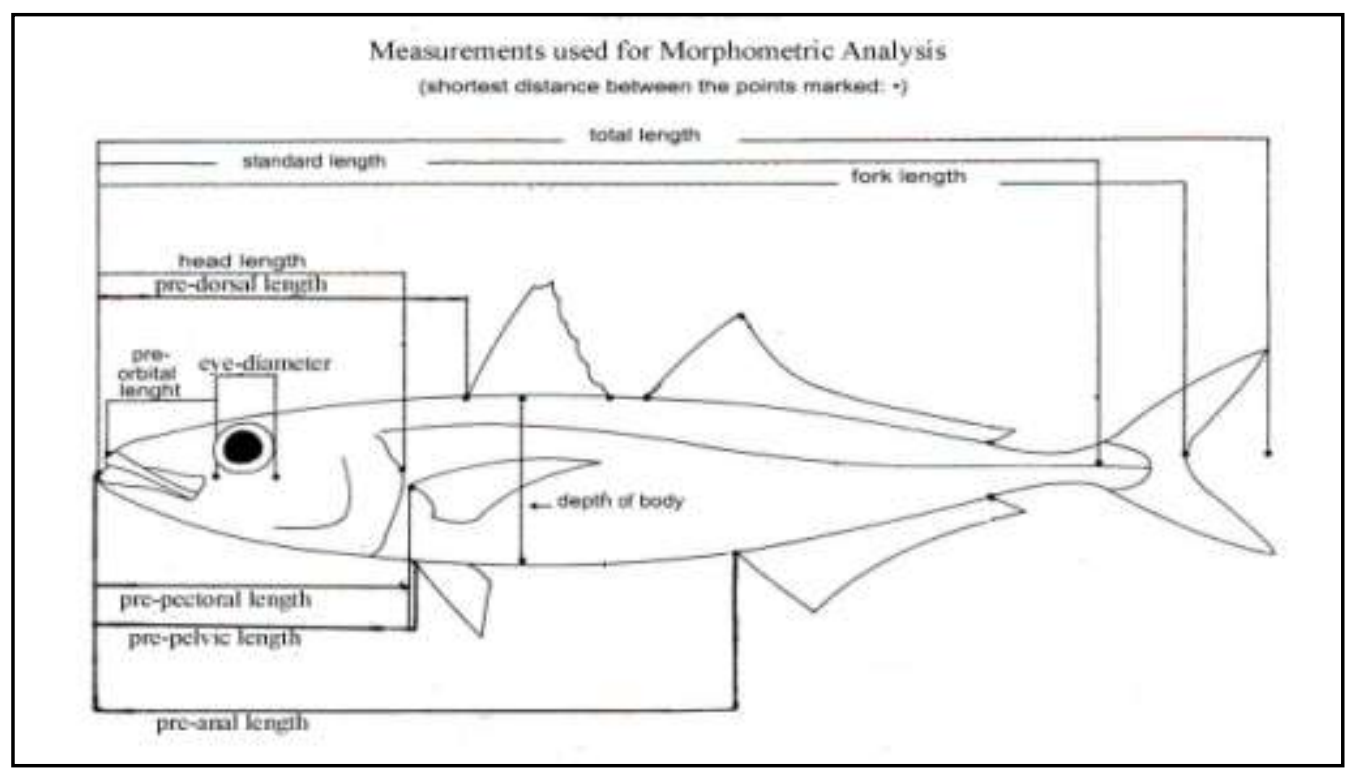

Fig 1: Measurements used for morphometric analysis of the selected species.

Table 1: Data of the measurements of the mean body parameters.

\begin{tabular}{|l|c|c|c|c|c|c|}
\hline \multirow{2}{*}{$\begin{array}{c}\text { Mean body } \\
\text { parameters }(\mathbf{c m})\end{array}$} & \multicolumn{7}{|c|}{ Species } \\
\cline { 2 - 7 } & $\begin{array}{l}\text { Puntius } \\
\text { chola }\end{array}$ & $\begin{array}{l}\text { Puntius } \\
\text { gelius }\end{array}$ & $\begin{array}{l}\text { Puntius } \\
\text { conchonius }\end{array}$ & $\begin{array}{l}\text { Puntius } \\
\text { sophore }\end{array}$ & $\begin{array}{l}\text { P. sarana } \\
\text { sarana }\end{array}$ & $\begin{array}{l}\text { P. ticto } \\
\text { ticto }\end{array}$ \\
\hline Total length & 6.555 & 3.133 & 7.046 & 7.127 & 14.043 & 4.116 \\
\hline Standard length & 4.949 & 2.422 & 5.721 & 5.794 & 11.094 & 3.334 \\
\hline Fork length & 5.591 & 2.745 & 6.384 & 6.436 & 12.091 & 3.737 \\
\hline Pre-anal length & 3.422 & 1.764 & 4.073 & 4.169 & 7.724 & 2.301 \\
\hline Pre- dorsal length & 2.491 & 1.184 & 3.016 & 2.737 & 5.491 & 1.782 \\
\hline Pre-pelvic length & 2.320 & 1.191 & 2.635 & 2.651 & 5.196 & 1.688 \\
\hline Pre-pectoral length & 1.403 & 0.548 & 1.261 & 1.112 & 2.584 & 0.799 \\
\hline Body depth & 1.776 & 0.815 & 2.452 & 2.302 & 3.441 & 1.309 \\
\hline Head length & 1.514 & 0.608 & 1.487 & 1.219 & 2.837 & 0.724 \\
\hline Eye diameter & 0.539 & 0.239 & 0.443 & 0.385 & 0.831 & 0.265 \\
\hline Pre-orbital length & 0.286 & 0.109 & 0.443 & 0.153 & 0.487 & 0.154 \\
\hline
\end{tabular}


Table 2: Data of the standardized body parameters.

\begin{tabular}{|l|c|c|c|c|c|c|}
\hline \multirow{2}{*}{$\begin{array}{l}\text { Standardized body } \\
\text { parameters: }\end{array}$} & \multicolumn{7}{|c|}{ Species } \\
\cline { 2 - 7 } & $\begin{array}{l}\text { Puntius } \\
\text { chola }\end{array}$ & $\begin{array}{l}\text { Puntius } \\
\text { gelius }\end{array}$ & $\begin{array}{l}\text { Puntius } \\
\text { conchonius }\end{array}$ & $\begin{array}{l}\text { Puntius } \\
\text { sophore }\end{array}$ & $\begin{array}{l}\text { Puntius sarana } \\
\text { sarana }\end{array}$ & $\begin{array}{l}\text { Puntius } \\
\text { ticto ticto }\end{array}$ \\
\hline $\begin{array}{l}\text { Total length (TL) : } \\
\text { Standard length }\end{array}$ & 1.33 & 1.29 & 1.23 & 1.23 & 1.27 & 1.24 \\
\hline TL : Fork Length & 1.17 & 1.14 & 1.11 & 1.11 & 1.16 & 1.10 \\
\hline TL : Pre-anal Length & 1.92 & 1.77 & 1.73 & 1.71 & 1.82 & 1.79 \\
\hline TL : Pre-dorsal Length & 2.63 & 2.65 & 2.33 & 2.60 & 2.56 & 2.31 \\
\hline TL : Pre-pelvic Length & 2.83 & 2.63 & 2.67 & 2.69 & 2.70 & 2.44 \\
\hline TL : Pre-pectoral Length & 4.69 & 5.69 & 5.60 & 6.42 & 5.44 & 5.15 \\
\hline TL : Body Depth & 3.69 & 3.82 & 2.88 & 3.10 & 4.08 & 3.17 \\
\hline TL : Head Length & 4.34 & 5.13 & 4.73 & 5.84 & 4.94 & 5.72 \\
\hline TL : Eye diameter & 12.15 & 13.04 & 16.02 & 18.76 & 16.92 & 15.26 \\
\hline TL : Pre-orbital Length & 22.62 & 28.45 & 16.02 & 47.53 & 28.65 & 27.47 \\
\hline
\end{tabular}

III. Results and Discussion:

The results of the correlation study and multivariate principal component analysis of the present study have been summarized in Table 3, Fig: $2 \mathrm{a}-2 \mathrm{j}$ and Table 4, Fig: 3 respectively. The coefficient of correlation was found to be maximum between Total length (TL) and Fork length $(r=0.9989)$ followed by TL and Standard length $(r=0.9988)$, TL and Pre-pelvic length $(r=0.9983)$, TL and Pre-anal length $(r=0.9973)$, TL and Pre- dorsal length $(r=0.9957)$, TL and Head length $(r=0.9846)$, TL and Pre-pectoral length $(r=0.9835)$, TL and Eye diameter $(r=0.9592)$, TL and Body depth $(r=0.9520)$ and the least correlation was found between TL and Pre-orbital length $(r=0.8008)$. . The correlation between TL and other morphometric parameters were found to be highly significant $(\mathrm{p}<0.05)$ except for TL and Pre-orbital length $(\mathrm{p}>0.05)$.

Table 3: Summary of the results of the correlation study between Total length and other morphometric parameters of the selected species.

\begin{tabular}{|l|l|c|c|}
\hline \multicolumn{2}{|c|}{ Morphometric Parameters } & $\begin{array}{c}\text { Coefficient of } \\
\text { correlation }(\mathbf{r})\end{array}$ & t - value [ t ] \\
\hline Total length & Standard length & 0.9988 & 40.767 \\
\hline Total length & Fork length & 0.9989 & 42.506 \\
\hline Total length & Pre-anal length & 0.9973 & 27.174 \\
\hline Total length & Pre- dorsal length & 0.9957 & 21.230 \\
\hline Total length & Pre-pelvic length & 0.9983 & 34.188 \\
\hline Total length & Pre-pectoral length & 0.9835 & 10.879 \\
\hline Total length & Body depth & 0.9520 & 6.218 \\
\hline Total length & Head length & 0.9846 & 11.253 \\
\hline Total length & Eye diameter & 0.9592 & 6.788 \\
\hline Total length & Pre-orbital length & 0.8008 & 2.674 \\
\hline
\end{tabular}

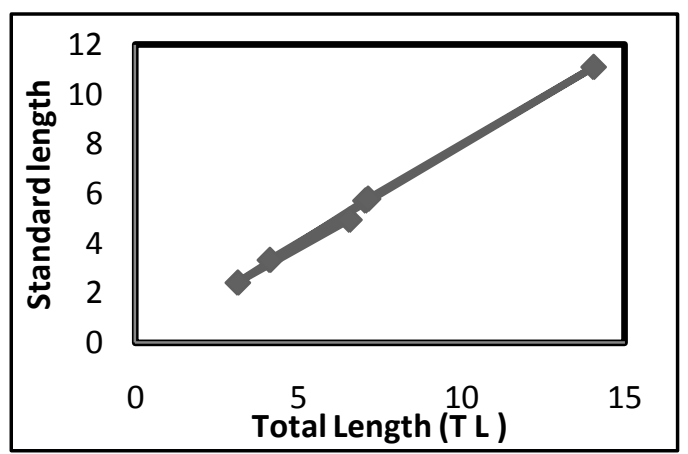

Fig 2a

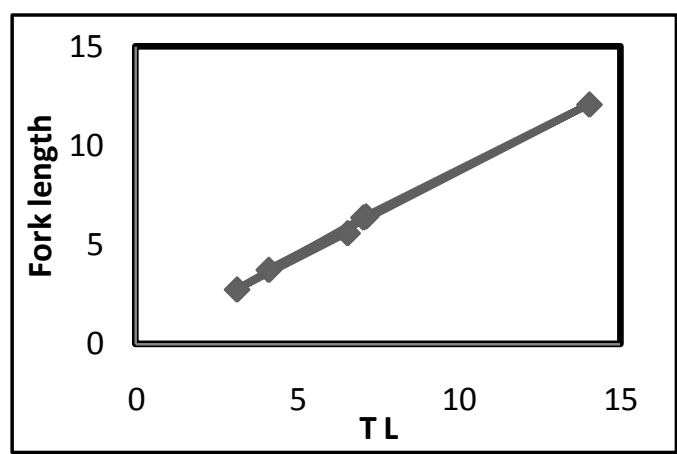

Fig 2b 


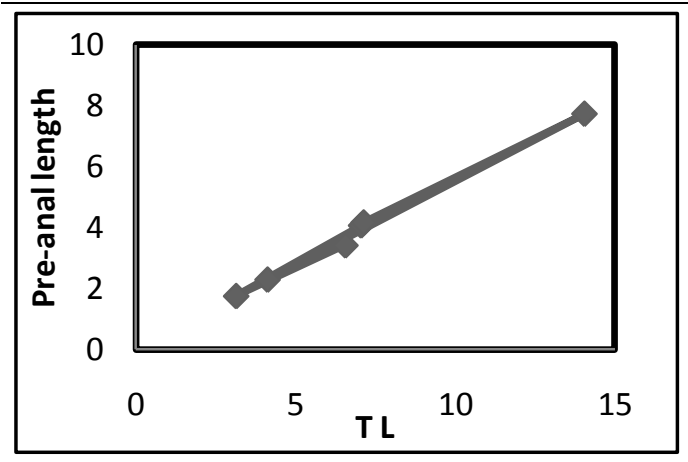

Fig 2c

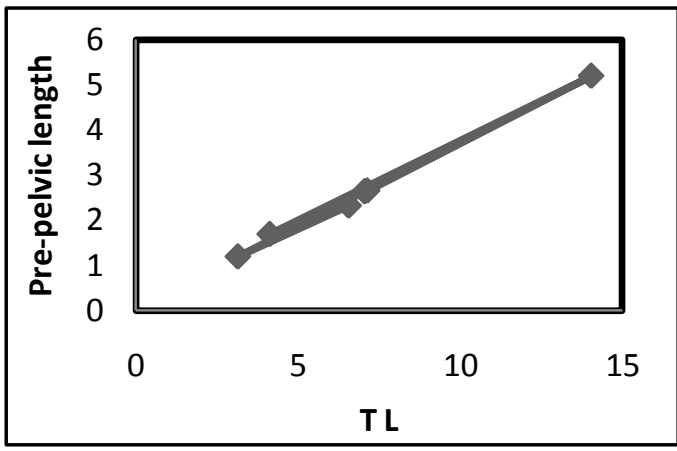

Fig 2e

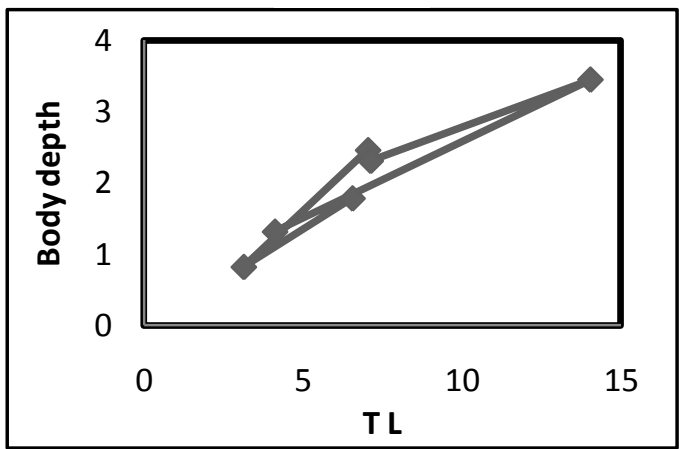

Fig $2 g$

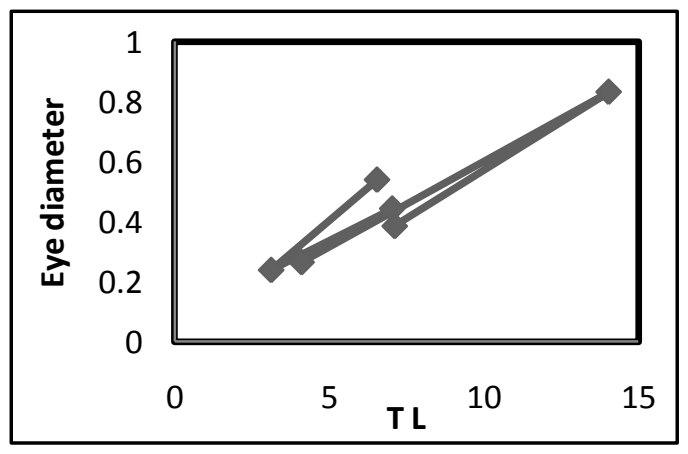

Fig $2 \mathrm{i}$

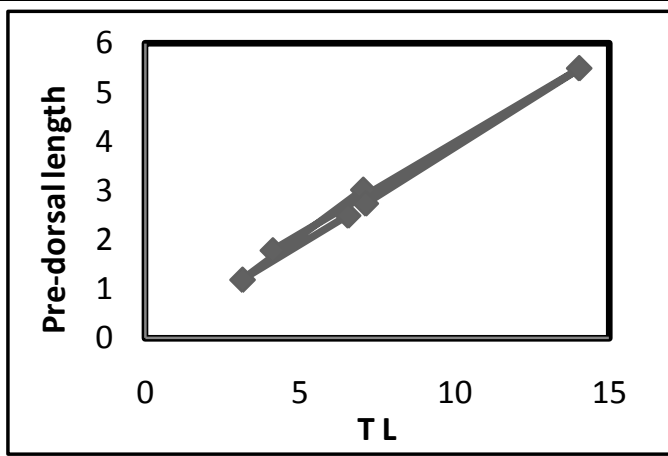

Fig 2d

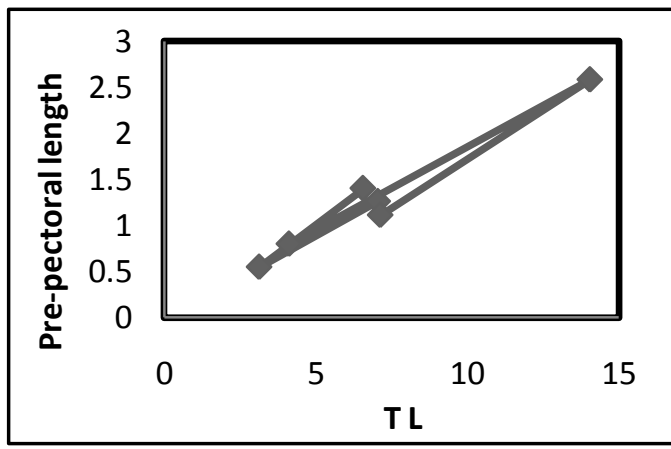

Fig $2 f$

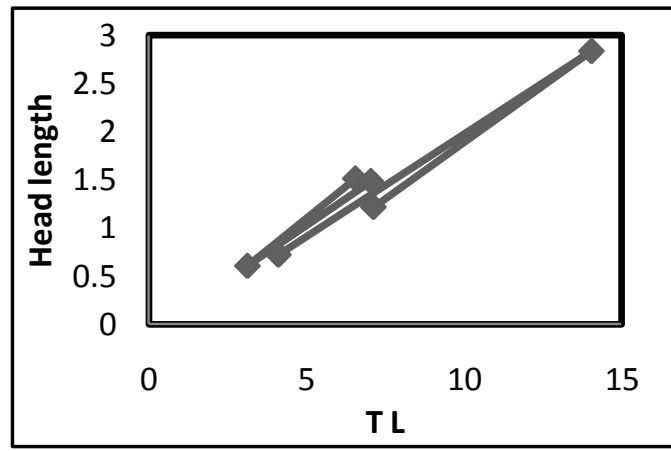

Fig $2 \mathrm{~h}$

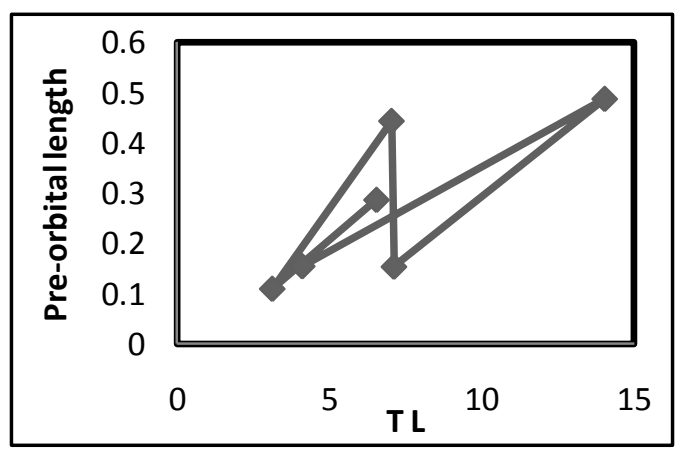

Fig $2 \mathbf{j}$

Fig 2a - 2j: Scatter plots showing the correlation between Total length and other morphometric parameters of the selected species.

Three principal components were extracted where the Eigen value of PC1 is $5.80195, \mathrm{PC} 2=2.36947$ and PC3 $=0.9929$. PC1 accounted for most of the variance. The scores of PC1, PC2 and PC3 of P. sarana sarana $(\mathrm{PC} 1=-10.17515, \mathrm{PC} 2=25.30209$ and $\mathrm{PC} 3=4.98392)$ and $P$. gelius $(\mathrm{PC} 1=-10.18856, \mathrm{PC} 2=$ 25.00737 and PC3 $=6.14143$ ) are most similar and the relative positions of these two species in a projection of 
the $1^{\text {st }}, 2^{\text {nd }}$ and $3^{\text {rd }}$ principal components in Fig: 3 indicates that they tend to group together. The PC1, PC2 and PC3 scores of $P$. sophore are the most different from the rest and its position (Fig: 3) indicates this species to be most distantly related.

Table 4: Summary of the results of the principal component analysis based on the variation in the standardized morphometric parameters of the selected species.

\begin{tabular}{|l|c|c|c|}
\hline Proportions & & & \\
\hline Eigenvalue & 5.80195 & 2.36947 & 0.9929 \\
\hline Components & & & \\
\hline Variable & PC1 & PC2 & PC3 \\
\hline Total length(TL) : Standard length & 0.39799 & 0.0861 & 0.15947 \\
\hline TL : Fork length & 0.38412 & 0.20522 & -0.04029 \\
\hline TL : Pre-anal length & 0.37533 & -0.08338 & 0.19689 \\
\hline TL : Pre-dorsal length & 0.21275 & 0.54169 & 0.03131 \\
\hline TL : Pre-pelvic length & 0.26109 & 0.28329 & -0.62441 \\
\hline TL : Pre-pectoral length & -0.31078 & 0.37726 & -0.22626 \\
\hline TL : Body depth & 0.29326 & 0.26326 & 0.35728 \\
\hline TL : Head length & -0.34352 & 0.16435 & 0.48895 \\
\hline TL : Eye diameter & -0.32128 & 0.23253 & -0.23921 \\
\hline TL : Pre-orbital length & -0.18959 & 0.52643 & 0.26111 \\
\hline Scores & & & \\
\hline Variable & $\mathbf{P C 1}$ & PC2 & PC3 \\
\hline P.chola & -7.06053 & 20.60796 & 4.23733 \\
\hline P.gelius & -10.18856 & 25.00737 & 6.14143 \\
\hline P.conchonius & -7.9467 & 18.01471 & 1.32324 \\
\hline P.sophore & -15.31731 & 35.9428 & 9.32315 \\
\hline P.sarana sarana & -10.17515 & 25.30209 & 4.98392 \\
\hline P. ticto ticto & -10.03012 & 23.85265 & 5.34101 \\
\hline
\end{tabular}

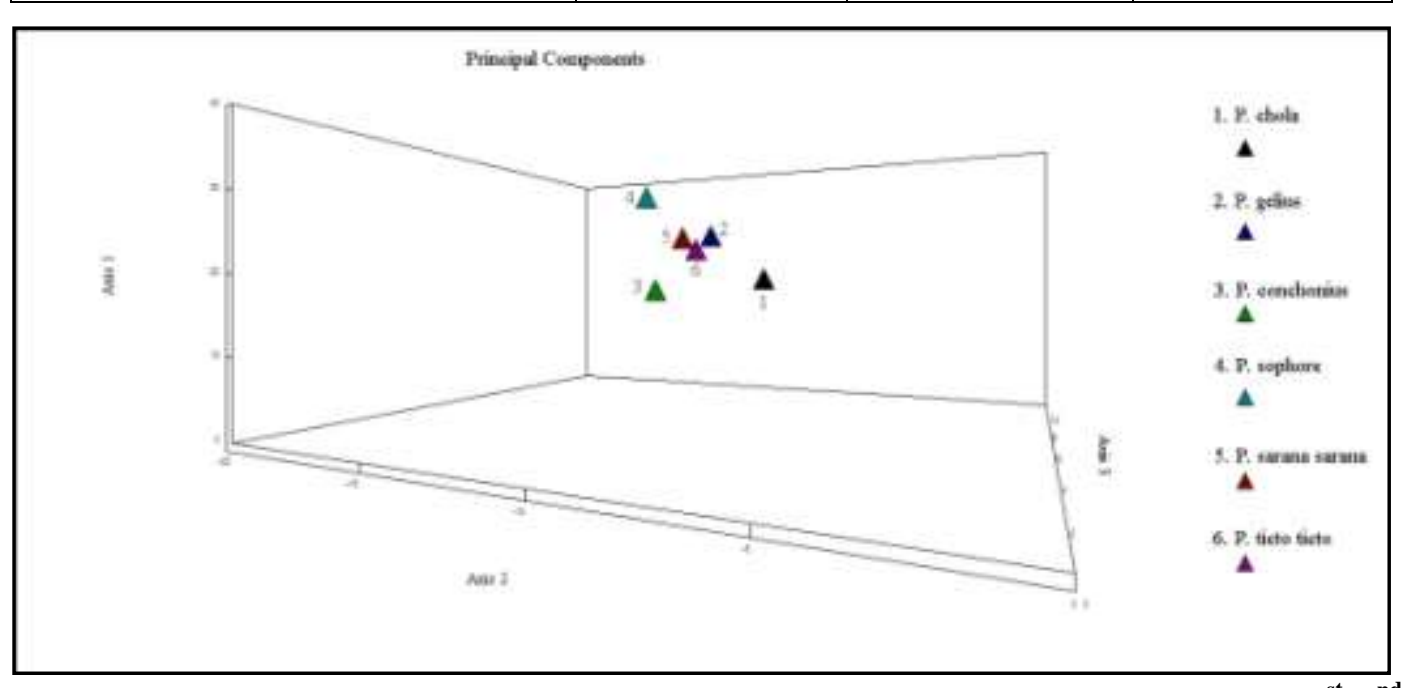

Fig 3: PCA output showing the relative positions of the selected species in a projection of the $1^{\text {st }}, 2^{\text {nd }}$ and $3^{\text {rd }}$ principal components.

The species of Puntius genus are identified conventionally based on morphological and meristic characters, relying mainly on the meristic counts, pigmentation pattern and colouration of the skin. The morphological approach cannot be used to establish the similarity/dissimilarity among the species i.e. taxonomic relationship among the species. The morphological approach is beset with problems including wide variation in the colour pattern between mating and non mating seasons of the same individuals of the same species. Thus, supportive techniques like the one we have used in this study are needed to ratify the taxonomic status and relationship of these species which are very important from both fisheries and aquaculture points of views. 
The results of the present investigation clearly showed the correlation between Total length and other morphometric parameters to be highly significant except for pre-orbital length. From the result of principal component analysis it was found that Puntius sarana sarana and P. gelius which are morphologically different are having most similar scores, inferring that these two species are most similar to each other and the descendents of a very near common ancestor. There is a strong superficial resemblance between $P$. chola and $P$. conchonius [14], but the present study has revealed that these two species are not closely related (Table 4, Fig: 3). P. sophore has a frontoparietal fontanel, which is not found in any other species of Puntius [15]. The present study also revealed that $P$. sophore being most distantly related with the close counterparts (Table 4, Fig: 3). The present study provides the pioneering report on the application of morphometric analysis of the selected species from this region. Morphometric studies have been widely used to discriminate the populations of various fish species [16] and have been able to identify differences between fish taxa [17]. [18] identified different variants in a fish species Etroplus maculatus by morphometric analysis. On the basis of morphometric variation, [19] identified the interrelationships of five Labeo species.

\section{Conclusion:}

Since the connectivity between species and their taxonomic relationship is a major point for conservation and management of species, the use of morphometry to this purpose appears to be very promising and the results of the present study may be a useful reference for further investigations and developing new strategies for conservation and breeding programmes of these species.

\section{Acknowledgement:}

The authors are grateful to CSIR, New Delhi, for providing the CSIR Senior Research Fellowship.

\section{References:}

[1] Parsons, K.J. Robinson, B.W. and Hrbek, T. Getting into shape: an empirical comparison of traditional truss-based morphometric methods with a newer geometric method applied to New World cichlids. Environ Biol Fishes, 67, $2003,417-431$.

[2] Rohlf, F.J. and Marcus, L.F. A revolution in morphometrics..Trends in Ecology and Evolution, 8, 1993, $129-132$.

[3] Bookstein, F. L. Morphometric tools for landmark data: geometry and biology (Cambridge, Cambridge Univ. Press, 1991).

[4] Loy, A., Corti, M. and Marcus, L.F. Landmark data: size and shape analysis in systematics. A case study on old world Talidae (Mammalia, Insectivora). In LFMarcus, E.Bellow, A.Garcia - Valdacases, (eds). Contributions to morphometrics, $1993,213-240$.

[5] Rohlf, F.J. Morphometric spaces, shape components and the effects of linear transformations. In LF Marcus, M.Corti, A.Loy, G.Naylor, DE Slice (eds). Advances in morphometrics. NATO ASI series. A life sciences Vol.284. New York: plenum, 1996, 117129.

[6] Humphries, J. Bookstein, F.L. Chernoff, B. Smith, G. Elder, R. and Poss, S. Multivariate discrimination by shape in relation to size. Syst. Zool. 30, 1981, 291-308.

[7] Bookstein, F., Chernoff, B., Elder, R., Humphries, J., Smith, G., and Strauss, R. Morphometrics in evolutionary biology (Special Publication 15: Philadelphia: The Academy of Natural Sciences of Philadelphia, 1985).

[8] Jayaram, K.C. The Freshwater Fishes of the Indian Region. Vol 27. (New Delhi, Narendra Publishing House, 1991$) 551$.

[9] Quilang, J. P., Basiao, Z. U., Pagulayan, R. C., Roderos, R. R. and Barrios, E. B. Meristic and morphometric variation in the silver perch, Leiopotherapon plumbeus (Kner, 1864), from three lakes in the Philippines. Journal of Applied Ichthyology, 23, 2007, 561567.

[10] Talwar, P.K. and A.G. Jhingran. Inland fishes of India and adjacent countries Vol 1. (A.A. Balkema, Rotterdam, 1991)

[11] Froese, R. and D. Pauly. Editors. FishBase. www.fishbase.org, 2010

[12] S. Choudhury, P. Saikia, N. Sougrakpam, D. Brahma and K.Dutta. Assessment of morphometric variation and establishing taxonomic relationship among six species under Puntius genus. The Ecoscan: Special issue, 1(1), 2011, $233-237$.

[13] Neil McAleece, P.J.D. Lambshead and G.L.J. Paterson. Originators . Biodiversity Pro. The Natural History Museum, London (Provider). 1997, URL: http://www.sams.ac.uk/

[14] Talwar, P.K. and A.G. Jhingran. Inland fishes of India and adjacent countries Vol 1. (A.A. Balkema, Rotterdam, 1991)

[15] Mirza, M. R. Freshwater Fishes and Zoogeography of Pakistan. (In: Bijdragen tot de Dierknnde, 1975$) 45$.

[16] Hurlbut, T. and Clay, D. Morphometric and meristic differences between Shallow and deepwater populations of White hake (Urophycis tenuis) in the southern Gulf of St Lawrence. Can. J. Fish. Aquat. Sci., 55, 1998, 2274-2282.

[17] Pollar, M., Jaroensutasinee, M. and Jaroensutasinee, K. Morphometric analysis of Tor tambroides by stepwise discriminant and neural network analysis. World Academy of Science, Engineering and Technology, 33, 2007, 16-20.

[18] Manimegalai, M. Karthikeyeni, S. Vasanth, S. Arul Ganesh, S. Siva Vijayakumar, T. and Subramanian, P. Morphometric Analysis A Tool to Identify the Different Variants in a Fish Species E. Maculatus. International Journal of Environmental Sciencs, 1(4), 2010, 481-497.

[19] Choudhury, S and Dutta, K. Interrelationships of five species of the genus Labeo by morphometric analysis. IOSR- J. of pharmacy and Biological Sciences. 2(6), 2012, 35 - 39. 